\title{
Durable Fiction: Danilo Kiš and his Library
}

\author{
Aleš Debeljak
}

As a historical and contemporary conglomerate of cultures and religions, languages and nations, the Balkans made their first imprint on the European public consciousness in the early nineteenth century. After the Greeks and a few other Balkan nations achieved statehood, they immediately subjected the diverse peoples on their territories to state-sponsored programs of ethnic homogenization. As a result, by the twentieth century, the legacy of Balkan hybridity, fluidity, and a mixture of ethnicities, languages, and cultures was preserved only in Yugoslavia. Today the "balkanisation" of a given community is a slur, suggesting the narcissistic fragmentation of large collectives into smaller splinter groups that assert themselves in bloodshed and hatred, the cunning moralism of purity, and the ritual evocation of ancient rights. The violent disintegration of the Yugoslav federation in the 1990s lent tragic support to this stereotype.

And yet a vibrant cultural tradition thrived in interwar Yugoslavia, a culture that encouraged and allowed the intense trafficking of ideas, attitudes, and symbols across linguistic and ethnic borders, and fostered an atmosphere of intellectual hybridity and cosmopolitanism. Ultimately, this tradition turned out to be more of a sliver than solid timber but nevertheless it fomented a movement called zenitism (zenithism), an historical avant-garde movement with an genuine Balkan twist. Ljubomir Micić edited the eponymous magazine for five years, turning it into a showcase for local experiments in German Expressionism and Russian Constructivism. His chauvinist idea of the barbaro-genius, the authentic Balkan man who in his creative zenith injects fresh blood into decadent and decaying Europe, perfectly captured the regionally popular belief that the Balkan peoples were untainted by corrupt European reason. The works of Slovenian poet Srečko Kosovel contained a trembling cadence of emancipatory prophecy. The poems of a Croatian poet Tin Ujević were full of insightful meditations on the passing of time. Ivo Andrić, whose work was claimed by Serbs, Croats and Bosniaks alike, expressed the fatalistic acceptance of misfortune. But none of these writers, all of whom reached beyond their own ethnic heritage, continues to have such a powerful attraction than Danilo Kiš.

\section{The Last Yugoslav Writer}

Danilo Kiš (1935-1989), an influential fiction writer, a prolific translator from French, Hungarian, and Russian, was a charismatic bon vivant. Jewish, Serbian, and Hungarian roots animated his cultural background. And yet, though he was born to a Jewish father and a Montenegrin mother, he proclaimed himself to be the child of the Argentinian writer Jorge Luis Borges and the Polish writer Bruno Schulz. He did not entirely reject ethnic allegiances, but rather than opting for any one of the collective identities on offered to him, he boldly embraced the ecumenical designation of the "last Yugoslav writer." This positioning allowed him to resist the appeal of the separate and competing nationalisms of his homeland. Following in his footsteps, I strive to this day to remain committed to the primordial realms of intimate geography, history, and community, even as I foster links to global cultural movements. Defying both the rigidity of nationalist navel-gazing and the blithe nonsense of global citizenship, I attempt, like Kišs, to trace the concentric circles of identity that emanate from images of the self, embedded in communal experience, 
and ripple outward into local, regional, and national identities.

This layered, hybrid, and multi-faceted identity is available only to the particular gaze that has the transformative power to erode locally entrenched descriptions of everyday life and turn them into stories of universal meaning. This is the gaze of artists and writers in whose work mature reflection travels in the same compartment as the commitment to a chosen community that is different from one's ethnic or linguistic group. Such a cosmopolitan perspective necessitates individual deliberation and moral choice. It necessitates choosing membership in an elusive community in which the imperative to be human is not merely a given right, but a responsibility as well. What protects those of us who still want to participate in a life in which the idea of common humanity has not yet withered away is the frail hope that a critical attitude toward exclusivist ideologies will give us the power to resist the status quo and prevent us from the cynical acceptance of evil.

\section{| Against Exclusivism}

Danilo Kiš was my writer-hero. I admired his moral insistence that the central question for writers of the twentieth century was the question of camps, of Auschwitz and the Gulag. I warmed to his lyrical procedures that accommodated both the litany of railway stations and the tremor of an anxious soul. I liked his claim that kitsch is as indestructible as a plastic bottle, his resigned, though not defeatist, realization that, having spent his last decade in voluntary Parisian exile, contemporary French intellectual debates were familiar to him, while the debates of his native realm would remain forever alien to his French peers. I cherished his persistence in the belief that literature is written with the totality of one's being, not with language alone, and this made him cling to his Serbo-Croat literary idiom despite the false comforts of French, the adopted language of his everyday life as an exile. I believed in his anti-nationalist hybridization of literary genres and cultural experiences, his opposition to the chauvinist elevation of "the chosen nation" to the level of a metaphysical Idea that justifies any and all means to advance its protection. With his ethical integrity and aesthetic practice, Kiš was the voice that inspired me most in my pursuit of the true cosmopolitan attitude.

I discovered Danilo Kiš in the early 1980s, when, as a student at the Ljubljana University, Slovenia, I shared the larger home of Yugoslavia with him. Coming across his stories was a revelation, and good luck, as his literary work had not been canonized yet. In fact, in the wake of the publication of his collection of short stories, The Tomb for Boris Davidovich (first published in 1976; two years later, Harcourt Brace Jovanovich published the English translation), a fierce controversy erupted over the proper use of literary methods. It was the biggest literary polemic in the small country at the time and Kiš was subject to the public character assassination and harassment by communist cronies that ultimately resulted in his emigration. Kiš went to live in France where he first taught Serbo-Croat at provincial universities and then settled in Paris. I went into the exile of his fiction. Three decades later, I am still its happy denizen. I continue to draw sustenance from Kiš, never more than today, in our world of capitalism without alternative. Of course I'm aware that to contemplate the consolations of library as a continuation of human community is to engage in what seems a vaguely indecent pursuit in these hard times, and yet I can't help but daydream. I daydream about books and reality, literature and mortality, I daydream about durable fiction of Danilo Kiš.

\section{The Importance of People Without Importance}

In his work, notably in the story Encyclopedia of the Dead (first published in 1983; Farrar, Strauss and Giroux published the English translation in 1989), Kiš exploited the metaphor of the library, and where there's a literary library, there's Jorge Luis Borges. It was Borges's meta-fictional strategy that made Kiš exclaim that the history of literature is divided into "before Borges and after him." The claim may be debated, but it is indisputable that Borges strongly influenced Kišss literary use of documents, chronicles, and fact-based references. Plowing through their respective claims to truth, Kiš created fictional works of the highest aesthetic order.

Borges devised a metaphor of a library whose aim was to be the universe. In his story The Library of Babel (1941), the library is enormous as it contains the infinity of all past, present, and future events. Borges' library is as 
unlimited as the anxiety of those who look in vain in the orderly rows of bookshelves for an explanation to chaos.

Kiš was impressed by Borges' library, but not content. He chose a sharp, passionate, and doubtless polemically pregnant rendition of the trope in Encyclopedia of the Dead. First, First, Kiš’s encyclopedia, the essential book in this library, is open only to those people who are already dead. Second, the selective mechanism is at work even within the community of the dead. Kišss library excluded all of those whose names had already merited inclusion in any other book, lexicon, or library. The people who didn't make it into any of the existing Who's Who reference books thus find sole recognition in the genuine encyclopedia of the dead, the encyclopedia of the nameless. This methodological gesture is nothing less than a celebration of the equalizing power of death. It is a macabre reminder of the frequently ignored principles of freedom, brotherhood, and equality.

The encyclopedia's entries weave a web of events, the lullabies sung by the deceased, the relatives and wedding guests, postmen with feather-light feet and diligent milkmaids, all the people the deceased used to see, know, smell. Each entry is endless. But isn't this obvious? The web that an individual life creates, after all, is so extensive that it literally captures the entire world, for every person sooner or later crosses paths with another person who has been in touch with the deceased man's acquaintance. As the web spreads to include relatives and relatives of relatives as well as acquaintances and casual encounters, the encyclopedia of the dead reveals its emancipatory potential, intimating that we are connected with all living and dead things and people in the world. This labyrinth, this impossible-tountangle skein of links, running both horizontally and vertically, is so vast that, during my first reading of Kišs story, I had the thrilling sense of discovering such an exceptionally accurate and detailed map of England, say, that was actually England itself, as Josiah Royce described in his book The World and the Individual (1899). Moreover such a map welcomes constant repetition ad infinitum, for every map of England must contain itself, and thus progressively accumulates multitudes of its own image.

Kiš's encyclopedia, however, represents the multitude that is always already there. But here the vocabulary of entries metamorphoses from the linear quality of ordinary written records that sets the norms of our everyday speech and our chronological lives into simultaneously present slices of life which all the deceased suffered through. The entire history of a person is summarized in a few sentences, defined not only by the tedious perspective of basic information - birth date, education, marital status, addresses changed, jobs held - but rather with an artistic sensibility that summons the most ambitious of ideals, the totality of being.

The Book, the secret project of Stephane Mallarme, shines through this unfulfilled desire to sing the totality of being, to live the totality of song. Mallarme, the founder of French Symbolism in the late nineteenth century, deified language and its capacity for a dream-like synthesis in which all self-division is overcome and "all earthly existence must ultimately be contained in the book." Mallarmé, to be sure, never wrote the Book. His maxim that everyone and everything that occurs in the world must one day arrive into the Book, however, was recuperated with aesthetic beauty and social sensitivity under the pen of Danilo Kiš. 
